\title{
Knowledge Management Maturity Model: A Case Study at Ministry XYZ
}

\author{
Nanik QODARSIH ${ }^{1}$, HANDAYANI $^{2 *}$, and Rela SABTIANA ${ }^{3}$
}

\author{
${ }^{I}$ Badan Litbang Diklat Kumdil Mahkamah Agung RI, Bogor-Indonesia \\ ${ }^{2}$ Balai Besar Pengujian Perangkat Telekomunikasi, Kementerian Komunikasi dan Informatika, Jakarta Indonesia \\ ${ }^{3}$ BPS kabupaten Kaur, Bengkulu-Indonesia
}

\begin{abstract}
Knowledge management (KM) has a very potential benefit, especially to deal with unstructured public issues and has no solution at all, requiring a public leadership to work, share, apply and create knowledge in many institutions. The Ministry of XYZ has built a Knowledge management system (KMS) that is used as a means of sharing knowledge of all XYZ's employees. However, KMS in XYZ is not running in accordance with the target. KMS in XYZ is not used as a two-way communication. Based on the problem, it can be identified that the level of KM maturity in XYZ is needed to be assessed. This study aims to determine the level of maturity of KM based on GKMMM maturity model and then make recommendations to improve the level of maturity of KM in XYZ. For data collection, G-KMMM based questionnaires were made online and spread through WhatsApp groups existing in the organization. A total of 70 questionnaires were collected. Based on the analysis, the maturity level of KM implementation in XYZ on five aspects of culture, policy, strategy, process and technology are at level 3. From this result, several strategies are recommended to improve the implementation of KM in the organization

Keywords: knowledge, Knowledge management, KM maturity, G-KMMM, The Ministry of XYZ

\section{INTRODUCTION}

Knowledge management (KM) has a very potential benefit, especially to deal with unstructured public issues and has no solution at all, requiring a public leadership to work, share, apply and create knowledge in many institutions, organizations and groups of citizens [1]. Organizations can begin implementing IT tools to facilitate knowledge in an organization. Knowledge management can assist public

used optimally, knowledge sharing in XYZ also cannot be managed properly. The Research Question of this paper is How good is the level of maturity level of knowledge management in XYZ? The main purpose of this final paper work is to determine the level of maturity of $\mathrm{KM}$ based on G-KMMM maturity model and then make recommendations to improve the level of maturity of $\mathrm{KM}$ in XYZ. Through this final work, researchers expect the benefits that can be obtained for organizations on improving the effectiveness of the application of $\mathrm{KM}$ in XYZ.
\end{abstract} organizations in identifying, selecting, organizing, disseminating and transferring vital information and expertise that are part of the organization's knowledge stored and information retrieval will be retrieved [2]. Based on [3] Knowledge Management Implementation should be driven based on business needs. Implementation of Knowledge Management requires a clear road map, which is derived based on the goals and resources available. To provide a roadmap for the implementation of Knowledge Management, many practitioners and researchers have developed a KM Maturity Model. The Ministry of XYZ is a government institution in Indonesia. XYZ has the task of organizing government affairs in the field of communications and informatics to assist the President in organizing the state government. Based on the interviews of $\mathrm{XYZ}$ personnel chiefs, it is known that employee mutation rates are high in $\mathrm{XYZ}$, as well as the retirement age of many more than young. Therefore, $\mathrm{KM}$ is essential for XYZ to improve organizational effectiveness. KM can potentially increase the effectiveness of public organizations [4]. KM in $\mathrm{XYZ}$ is expected to support XYZ's strategic objective of supporting the employee's mental revolution, but currently KM at XYZ has not been well managed. as an example of KMS that has not been

\section{THEORY}

Knowledge refers to information that enables action and decisions or information with direction [7]. [8] concocted the two kinds of knowledge which are explicit and tacit. The coordination of both tacit and explicit knowledge across several organizational dimensions in order to create value, which may in turn be defined in different ways, according to the objectives the organization wishes to achieve is defined as knowledge management [9]. [10] proposes the meaning of KM as an efficient approach (with a foundation in data innovation, human resource, technique, and hierarchical conduct) that implicit and explicit knowledge as a key vital asset and goes for enhancing the treatment of information at the individual, group, association and between authoritative level so as to enhance advancement, quality, cost-adequacy and time to advertise. In order to evaluate the implementation of knowledge management, it is needed to measure the maturity model. Based on the previous studies, there are many existing maturity models as shown in Table 1 below. 
Table 1 model names and authors of extended (k. kuriakose, 2009) morphological analysis [12]

\begin{tabular}{|c|c|c|c|c|}
\hline No & MODEL NAME & Author & $\begin{array}{l}\text { CMM- } \\
\text { based }\end{array}$ & Stage \\
\hline 1 & $\begin{array}{l}\text { KMMM } \\
\text { (Infosys) }\end{array}$ & $\begin{array}{l}\text { V.P Kochikar } \\
(2000)\end{array}$ & Yes & 5 \\
\hline 2 & $\begin{array}{l}\text { KMMM } \\
\text { (APQC) }\end{array}$ & Hubert (2009) & No & 5 \\
\hline 3 & KMCA & $\begin{array}{l}\text { Kulkarni U } \\
\text { (2004) }\end{array}$ & Yes & 6 \\
\hline 4 & KMMM & Klimko (2001) & No & 5 \\
\hline 5 & $\begin{array}{l}\text { Knowledge } \\
\text { Journey }\end{array}$ & $\begin{array}{l}\text { KPMG } \\
\text { Consulting } \\
\text { (2000) }\end{array}$ & No & 5 \\
\hline 6 & $\begin{array}{l}\text { KMMM } \\
\text { (Software } \\
\text { Industry) }\end{array}$ & $\begin{array}{l}\text { Natarajan } \\
(2005)\end{array}$ & Yes & 4 \\
\hline 7 & KPQM & $\begin{array}{l}\text { Paulzan, } \\
\text { Dourni, \& } \\
\text { Roibas (2002) }\end{array}$ & Yes & 4 \\
\hline 8 & 5iKM3 & $\begin{array}{l}\text { TATA } \\
\text { Consultancy, } \\
\text { Mohanty and } \\
\text { Chand (2005) }\end{array}$ & No & 5 \\
\hline 9 & $\mathrm{~K} 3 \mathrm{M}$ & $\begin{array}{l}\text { Wisdom Source } \\
\text { (2004) }\end{array}$ & No & 8 \\
\hline 10 & $\begin{array}{l}\text { KMMM } \\
\text { (Technology) }\end{array}$ & $\begin{array}{l}\text { Gottschalk } \\
(2002)\end{array}$ & No & 4 \\
\hline 11 & $\begin{array}{l}\text { KMMM } \\
\text { (Siemens) }\end{array}$ & $\begin{array}{l}\text { Ehmsand } \\
\text { Langen (2002) }\end{array}$ & Yes & 5 \\
\hline 12 & $\begin{array}{l}\text { Strategic } \\
\text { KMMM }\end{array}$ & $\begin{array}{l}\text { Kruger and } \\
\text { Snyman (2007) }\end{array}$ & Yes & 6 \\
\hline 13 & KM3 & $\begin{array}{l}\text { Gallagher and } \\
\text { Hazlett }\end{array}$ & No & 4 \\
\hline 14 & G-KMMM & $\begin{array}{l}\text { Pee and } \\
\text { Kankanhalli } \\
(2009)\end{array}$ & Yes & 5 \\
\hline 15 & $\begin{array}{l}\text { KMMM } \\
\text { (Nuclear } \\
\text { Industry) }\end{array}$ & $\begin{array}{l}\text { Boyles et. al. } \\
\text { (2009) }\end{array}$ & Yes & 5 \\
\hline 16 & $\begin{array}{l}\text { KMMM } \\
\text { (Serna) }\end{array}$ & Serna (2012) & No & 5 \\
\hline 17 & V-KMMM & $\begin{array}{l}\text { Weerdemeister } \\
(2003)\end{array}$ & No & 4 \\
\hline 18 & $\begin{array}{l}\text { Frid } \\
\text { Framework }\end{array}$ & Frid (2003) & No & 5 \\
\hline 19 & Feng KMMM & Feng (2006) & No & 5 \\
\hline 20 & $\begin{array}{l}\text { KMMM } \\
\text { Engineering } \\
\text { Approach }\end{array}$ & $\begin{array}{l}\text { Kuriakose } \\
\text { (2011) }\end{array}$ & Yes & 5 \\
\hline
\end{tabular}

Generally, maturity model consists of four to six levels. Each level can be accomplished without skipping any level from bottom to top. Since the introduction of Capability Maturity Model (CMM), many maturity models were developed including Knowledge Management Maturity Model (KMMM). However, beside CMM based KMMM, there is also Non-CMM based KMMM. Originally, CMM consists of five maturity level but the adoption of CMM 
based KMMM can have different maturity level. The comparison of existing CMM based KMMM level is shown in Table 2.

Table 2 a comparison of existing cmm-based $\mathrm{kmmm}$ level [11]

\begin{tabular}{|l|l|l|l|c|c|l|}
\hline \multicolumn{1}{|c|}{ Level } & \multicolumn{1}{|c|}{ CMM } & $\begin{array}{c}\text { Siemen's } \\
\text { KMMM }\end{array}$ & KPQM & $\begin{array}{c}\text { Infosys'KMM } \\
\text { M }\end{array}$ & KMCA & G-KMMM \\
\hline 0 & & & & & $\begin{array}{c}\text { Difficult/Not } \\
\text { Possible }\end{array}$ & \\
I & Initial & Initial & Initial & Default & Possible & Initial \\
II. & Repeatable & Repeatable & Aware & Reactive & Encourage & Repeatable \\
III & Defined & Defined & Established & Aware & $\begin{array}{c}\text { Enabled/Practic } \\
\text { ed }\end{array}$ & Defined \\
IV & Managed & Managed & $\begin{array}{c}\text { Quantitatively } \\
\text { Managed }\end{array}$ & Convinced & Managed & Managed \\
V & Optimizing & Optimizing & Optimizing & Sharing & $\begin{array}{c}\text { Continuously } \\
\text { Improving }\end{array}$ & Optimizing \\
\hline
\end{tabular}

In this study, G-KMMM is used to measure the maturity model in the organization. G-KMMM is CMM-based KMMM developed by [11]. G-KMMM comprises of three key process areas (KPA) specifically, people, process and technology. People centers around culture, policy, and strategy. Process zone centers around information administration procedures and technology territory explores the technology identified with vision about KM innovation and foundation [12]. As with knowledge-oriented models, G-KMMM is created in light of the commence that learning is an important resource that develop associations can viably underwrite to enhance hierarchical execution and return benefit. Dissimilar to these models, G-KMMM additionally accentuates the transformative idea of $\mathrm{KM}$ where execution endeavors expand on each other [11].

The reasons of using this model are as follows. First, this model was first conducted by [11] in the public university which is in sync with this case study. This study is conducted in XYZ, a government institution. Moreover, [12] stated that this model was applicable to public or industry sector (general). In his research, [12] used this model in public institutions in Turkey. Second, this model is eligible to be applied to different objects of analysis, well it is the organization in general and independently for their respective units [13]. Third, this model consists of KPAs which are eligible to be applied in measuring maturity model in XYZ. Fourth, this model has an instrument assessment that can be used after some adjustments to XYZ's organizational condition. Furthermore, the model gives an exceptionally itemized clarification of the assessment instrument to give a deliberate and organized approach that ensures the straightforwardness of the assessment system. Fifth, this model consists of an adoption of a sorted-out structure and unmistakably characterizes each level of maturity and its key process areas, and their particular characteristics.

Table 2 shows that G-KMMM consists of five maturity levels. At Level 1, Initial, the association has practically no aim to utilize hierarchical learning. Information isn't considered a basic resource for the association by representatives. Individuals don't know how to oversee information assets. There are no predetermined procedures to gain, spread or reuse tasks. Also, there are no advancements bolsters KM activities.

At Level 2, Repeatable, association considers information as a benefit and administrators know that KM is need. Documentation forms are experienced; moreover, little pilot ventures are performed through the association.

At Level 3, Defined, authoritative information administration is characterized plainly and it sets up an essential framework that backings learning. Administration underpins the learning sharing tasks of the representatives. Procedures are formalized and KM measurements are utilized to build profitability that is identified with KM. Innovation use improves learning sharing tasks which implies that essential framework can be specified.

At Level 4, Managed/Established, Knowledge Management is inside the entire association. Information is a vital resource in the association procedure and individual and gathering preparing are institutionalized. KM forms are estimated quantitatively (i.e. measurements). Endeavor wide KM frameworks are set up and distinctive frameworks are coordinated to give greater profitability. At Level 5, Optimizing/Sharing, Organizational sharing is systematized; likewise, KM procedures and innovations are ceaselessly made strides.

\section{METHOD}

In order to collect data, an interview was conducted to identify the issue in the organization. And in order to respond to our research question, a survey was conducted, which was generated to ask respondents to give their opinion of knowledge management maturity model. The questionnaires were divided into seven parts. The first part is the identity of the respondents. The second to sixth part was made up of a total of 57 questions related to the knowledge management maturity model from the respondent perspective which was adopted from G-KMMM. And the last one is an obstacle aspect.

The questionnaire categories are shown in the Table 3 . below. 
Table 3 questionnaire categories and number of questions

From second to sixth part, the Likert scale of 1 to

\begin{tabular}{|l|l|c|}
\hline \multicolumn{1}{|c|}{ Part } & \multicolumn{1}{|c|}{ CATEGORIES } & Number of Questions \\
\hline I & Respondent's Identity & 6 \\
II. & Culture & 12 \\
III & Policy & 11 \\
IV & Strategy & 8 \\
V & Process & 15 \\
VI & Technology & 11 \\
VII & Obstacles & 1 \\
\hline
\end{tabular}

4 was used to answer the questions. The scale was shown in Table 4. as follows.

Table 4 the scale of answer and description

\begin{tabular}{|cc|}
\hline SCALE & Description \\
\hline 1 & Strongly disagree \\
2 & Disagree \\
3 & Agree \\
4 & Strongly agree \\
\hline
\end{tabular}

The questionnaire was made online using online form and distributed online through whatsapp groups exist in the organization for about a week. From the questionnaires sent out that were answered, a total 70 questionnaires

\section{DATA ANALYSIS AND RESULTS}

The questionnaires were distributed for 1 week through several whatsapp groups. Number of valid questionnaires returned by 70 respondents.

\section{Demographics}

The ministry of XYZ consist of 7 units of esselon 1 , from 7 units of esselon 1 equivalent, the highest number of respondents came from Directorate General of Informatics Applications as many as 27 respondents $(38.6 \%)$, followed by Secretariat General of XYZ as many as 14 respondents (20\%), Directorate General of Posts and Informatics Operations as many as 9 respondents (12.9\%), Directorate General of Resources Management and Equipment of Posts and Informatics as many as 7 respondents (10\%), Inspectorate General as many as 5 respondents (7.1\%), Agency for Human Resources Development and Research collected. A total of 70 questionnaires were therefore processed and analyzed for measuring maturity model. The data collected were processed and analyzed using Microsoft Excel spreadsheet.

on Communications and Informatics as many as 5 respondents $(7.1 \%)$ and Directorate General of Public Information and Communications as much as 3 respondents $(4.3 \%)$ can be shown at Table 5 .

This study consists of 70 respondents, the number of male respondents is more that 50 people compared to female respondents as many as 20 people (Table 6). There are 63 respondents who fill their structural positions with details of 2 esselon 2, 4 esselon 3, 35 esselon 4 and 22 staffs. (Table 7).

Based on the age of respondents, 31-40 years of productive age range of 51 people and age range 51-60 years as many as 2 people. (Table 8 ) 
Table 5 Work unit of respondents

\begin{tabular}{|l|c|}
\hline \multicolumn{1}{|c|}{ Unit } & Respondents \\
\hline ĐG of Application Informatics & 27 \\
Secretariat General & 14 \\
$\begin{array}{l}\text { DG of Posts and Informatics } \\
\text { Operations }\end{array}$ & 9 \\
$\begin{array}{l}\text { Directorate General of Resources } \\
\text { Management and Equipment of Posts } \\
\text { and Informatics }\end{array}$ & 7 \\
$\begin{array}{l}\text { Inspectorate General } \\
\text { Agency for Human Resources }\end{array}$ & 5 \\
$\begin{array}{l}\text { Development and Research on } \\
\text { Communications and Informatics }\end{array}$ & 5 \\
$\begin{array}{l}\text { Directorate General of Public } \\
\text { Information and Communications }\end{array}$ & 3 \\
\hline Total & 70 \\
\hline
\end{tabular}

Table 6 genders of respondents

\begin{tabular}{|cc|}
\hline Gender & Respondents \\
\hline Male & 50 \\
Female & 20 \\
\hline Total & 70 \\
\hline
\end{tabular}

Table 7 structural position of respondents

\begin{tabular}{|cc|}
\hline Structural position & Respondents \\
\hline Echelon 2 & 2 \\
Echelon 3 & 4 \\
Echelon 4 & 35 \\
Staff & 22 \\
\hline Total & 63 \\
\hline
\end{tabular}

Table 8 age of respondents

\begin{tabular}{|cc|}
\hline Age range & Respondents \\
\hline $20-30(\mathrm{Yo})$ & 3 \\
$31-40(\mathrm{Yo})$ & 51 \\
$41-50(\mathrm{Yo})$ & 14 \\
$51-60(\mathrm{Yo})$ & 2 \\
\hline Total & 70 \\
\hline
\end{tabular}




\section{The Measurement of indicators for each aspect}

Data collected questionnaires processed to measure the level kemaatangannya for every aspect. There are 5 aspects that will be measured that is culture, policy, strategy, process and technology.

\section{Culture}

In the culture aspect there are 12 questions to measure the maturity level of XYZ knowledge management. Of the 12 questions are grouped into 4 levels of questions ranging from level 2 to level 5. The analysis of each indicator on the culture aspects shown in Figure 1.

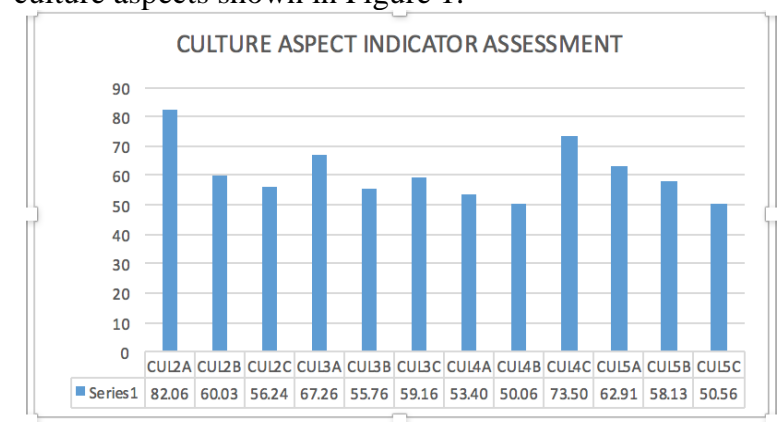

Figure 1. Culture Aspect Indikator Assessment

In the culture aspect all indicators are above $50 \%$. There are 3 low indicators that need to be improved related:

- CUL4A: Employees should be encouraged to document lessons learned, knowledge sharing and reusing knowledge on each of their routine jobs.

- CUL4B: The existing KM system should be developed into a reference and a major search of knowledge.

- The existing CUL5B KM system should also be encouraged to be used for sharing knowledge information outside the work environment but still beneficial to the organization.

Culture aspect at XYZ has met the level 3 maturity level.

\section{Policy}

In the policy aspect there are 11 questions to measure the maturity level of XYZ knowledge management. Of the 11 questions are grouped into 4 levels of questions ranging from level 2 to level 5. The analysis of each indicator on the policy aspect shown in Figure 2.

\section{POLICY ASPECT INDICATOR ASSESSMENT}

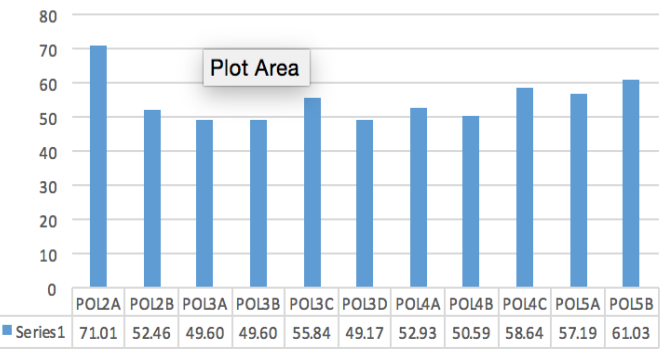

Figure 2. Policy Aspect Indikator Assessment

In the Policy aspect there are 3 indicators below 50\% that need to be improved are:

- POL3A: Need to improve the role and commitment of XYZ management in managing knowledge management.

- POL3B: XYZ needs to apply formal division of duties and responsibilities to officials or staff in the knowledge management process.

- POL3D: XYZ needs to provide knowledge management training and guidance on the use of KM System to new employees.

Policy aspect at XYZ has fulfilled level 3 maturity level.

\section{Strategy}

In the strategy aspect there are 8 questions to measure the maturity level of XYZ knowledge management. Of the 8 questions are grouped into 4 levels of questions ranging from level 2 to level 5. The analysis of each indicator on the strategy aspect shown in Figure 3.

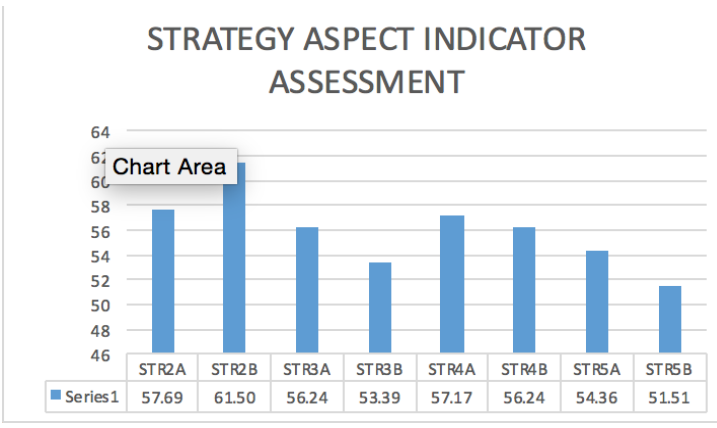

Figure 3. Strategy aspect indicator assessment

In the strategy aspect, all indicators are above $50 \%$. The 3 lowest indicators are:

- $\quad$ STR5B: XYZ management / leadership should make decisions based on ROI analysis (Return on investment).

- STR3B: XYZ needs to make KM development plans.

- $\quad$ STR5A: Management / management should use $\mathrm{KM}$ as the basis for decision making and $\mathrm{XYZ}$ strategy

Strategy aspect at XYZ has met level 3 maturity level. 


\section{Process}

In the process aspect there are 15 questions to measure the maturity level of XYZ knowledge management. Of the 15 questions are grouped into 4 levels of questions ranging from level 2 to level 5. The analysis of each indicator on the aspect of the process is shown in Figure 4.

PROCESS ASPECT INDICATOR ASSESSMENT

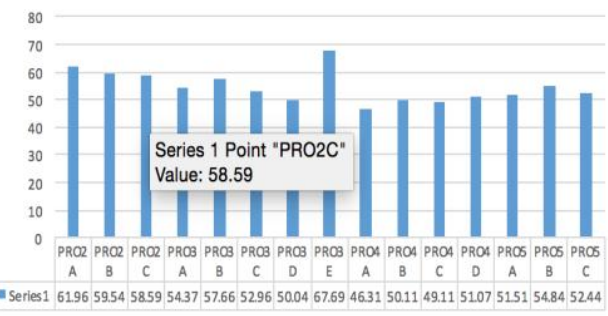

Figure 4. Process Aspect Indikator Assessment

In the process aspect, there are 2 indicators below $50 \%$, that is:

- PRO4A: In implementing the KM process there needs to be guidelines and examples from management.

- PRO4C: The KM process needs to be measured, to determine the current conditions of $\mathrm{KM}$ implementation and to identify the improvements that need to be made to improve the effectiveness of $\mathrm{KM}$ implementation.

Process aspect at XYZ has fulfilled level 3 maturity level.

\section{Technology}

In the technology aspect there are 12 questions to measure the maturity level of XYZ knowledge management. Of the 12 questions are grouped into 4 levels of questions ranging from level 2 to level 5. The analysis of each indicator on the technology aspect is shown in Figure 5.

\section{TECHNOLOGY ASPECT INDICATOR ASSESSMENT}

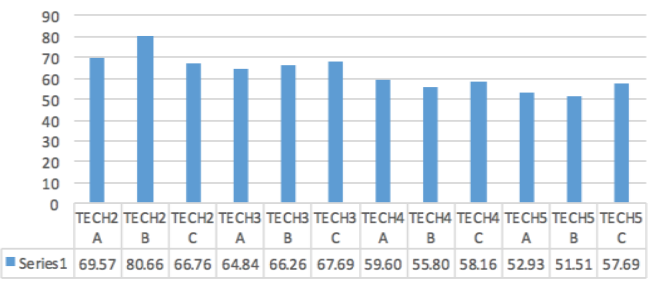

Figure 5. Technology Aspect Indikator Assessment

In the technology aspect, all indicators are above $50 \%$. There is one indicator on the threshold:

TECH5B: There needs to be consistency of management/leadership in updating, developing and evaluating KM System that exist regularly.
Technology aspect at XYZ has met level 3 maturity level.

\section{Barriers of KM Implementation}

There are 5 (five) main things that hinder the application of $\mathrm{KM}$ in $\mathrm{XYZ}$ as shown in Figure 6 are: No guidance and training

- No awareness

- No management policy

- Not included in the job assessment

- No role of management

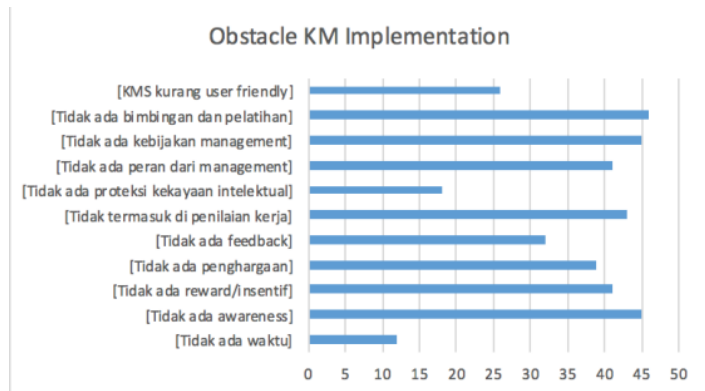

Figure 6. Obstacle KM Implementation

\section{CONCLUSION}

The maturity level is calculated based on contribution per aspect as shown in table 9 . 
Table 9 Maturity calculation based on contribution

\begin{tabular}{|c|c|c|c|c|c|c|c|}
\hline \multirow[b]{2}{*}{ Aspect } & $x$ & $A$ & $B$ & $C$ & $D$ & $E$ & $F$ \\
\hline & $\begin{array}{c}\text { Maturity } \\
\text { Level }\end{array}$ & $\begin{array}{c}\text { Sum of } \\
\text { Statement } \\
\text { Compliance } \\
\text { Value } \\
\end{array}$ & $\begin{array}{c}\text { Number of } \\
\text { Maturity } \\
\text { Level } \\
\text { Statements }\end{array}$ & $\begin{array}{c}\text { Maturity } \\
\text { Level } \\
\text { Compliance } \\
\text { Value }(A / B)\end{array}$ & $\begin{array}{l}\text { Normalized } \\
\text { Compliance } \\
\text { Values } \\
\text { (C/Sum C) }\end{array}$ & $\begin{array}{c}\text { Contribution } \\
(X / D)\end{array}$ & $\begin{array}{c}\text { Maturity } \\
\text { Level }\end{array}$ \\
\hline \multirow{5}{*}{ Culture } & 2 & 1.98 & 3 & 0.66 & 0.27 & 0.54 & \multirow{5}{*}{3} \\
\hline & 3 & 1.82 & 3 & 0.61 & 0.25 & 0.75 & \\
\hline & 4 & 1.76 & 3 & 0.59 & 0.24 & 0.97 & \\
\hline & 5 & 1.71 & 3 & 0.57 & 0.24 & 1.18 & \\
\hline & Total & & & 2.42 & 1.00 & 3.44 & \\
\hline \multirow{5}{*}{ Policy } & 2 & 1.23 & 2 & 0.41 & 0.16 & 0.32 & \multirow{5}{*}{3} \\
\hline & 3 & 2.04 & 4 & 0.68 & 0.27 & 0.80 & \\
\hline & 4 & 3.21 & 3 & 1.07 & 0.42 & 1.68 & \\
\hline & 5 & 1.18 & 2 & 0.39 & 0.15 & 0.77 & \\
\hline & Total & & & 2.55 & 1.00 & 3.57 & \\
\hline \multirow{5}{*}{ Strategy } & 2 & 1.19 & 2 & 0.40 & 0.27 & 0.53 & \multirow{5}{*}{3} \\
\hline & 3 & 1.09 & 2 & 0.36 & 0.24 & 0.73 & \\
\hline & 4 & 1.13 & 2 & 0.38 & 0.25 & 1.01 & \\
\hline & 5 & 1.05 & 2 & 0.35 & 0.24 & 1.18 & \\
\hline & Total & & & 1.49 & 1.00 & 3.46 & \\
\hline \multirow{5}{*}{ Process } & 2 & 1.8 & 3 & 0.60 & 0.22 & 0.44 & \multirow{5}{*}{3} \\
\hline & 3 & 2.82 & 5 & 0.94 & 0.35 & 1.04 & \\
\hline & 4 & 1.96 & 4 & 0.65 & 0.24 & 0.96 & \\
\hline & 5 & 1.58 & 3 & 0.53 & 0.19 & 0.97 & \\
\hline & Total & & & 2.72 & 1.00 & 3.41 & \\
\hline \multirow{5}{*}{ Technology } & 2 & 2.16 & 3 & 0.72 & 0.29 & 0.58 & \multirow{5}{*}{3} \\
\hline & 3 & 1.98 & 3 & 0.66 & 0.26 & 0.79 & \\
\hline & 4 & 1.73 & 3 & 0.58 & 0.23 & 0.92 & \\
\hline & 5 & 1.62 & 3 & 0.54 & 0.22 & 1.08 & \\
\hline & Total & & & 2.50 & 1.00 & 3.38 & \\
\hline
\end{tabular}

Based on the analysis, the maturity level of $\mathrm{KM}$ implementation in XYZ on 5 aspects of culture, policy,

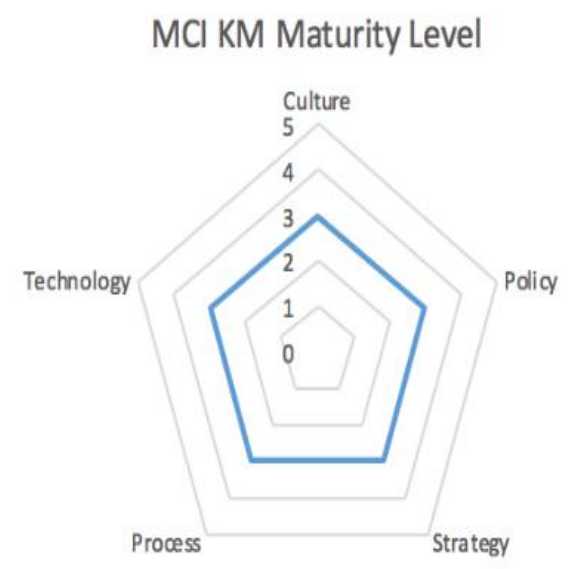

Figure 7. XYZ knowledge management maturity level

The proposed strategy for improving KM implementation in XYZ based on the analysis of $5 \mathrm{KPA}$ and obstacles is shown in Table 10 below. strategy, process and technology are at level 3, as can be seen in Figure 7. 
Table $10 \mathrm{KPA}$ and strategies

\begin{tabular}{|c|c|}
\hline KPA & Strategies \\
\hline Culture & $\begin{array}{l}\text { Management applies reward schemes, rewards and } \\
\text { incentives for employees who share knowledge. } \\
\text { Leaders need to provide motivation and examples } \\
\text { of how to do knowledge sharing. }\end{array}$ \\
\hline Policy & $\begin{array}{l}\text { Formation of policies that encourage the } \\
\text { implementation of KM eg make knowledge } \\
\text { sharing as an added value in performance appraisal } \\
\text { Formation of formal management to manage KM } \\
\text { in the organization. }\end{array}$ \\
\hline Strategy/Process & $\begin{array}{l}\text { Preparation of the framework to measure the } \\
\text { implementation of KM periodically so that it can } \\
\text { be improved. }\end{array}$ \\
\hline Technology & $\begin{array}{l}\text { Provide user friendly KMS and accommodate KM } \\
\text { (discovery, capture, sharing and application) } \\
\text { processes within the organization. } \\
\text { Provides reliable network access. }\end{array}$ \\
\hline
\end{tabular}

\section{ACKNOWLEDGMENT}

This research was financially supported by the Badan Litbang Diklat Kumdil Mahkamah Agung RI.

\section{REFERENCES}

[1] S. S. Dawes, A. M. Cresswell, and T. A. Pardo, "From 'Need to Know' to 'Need to Share': Tangled Problems, Information Boundaries, and the Building of Public Sector Knowledge Networks," Wiley Online Libr., vol. 69, no. 3, 2009.

[2] A. Desai and S. Rai, "Knowledge Management for Downstream Supply Chain Management of Indian Public Sector Oil Companies," Procedia Comput. Sci., vol. 79, pp. 1021-1028, 2016.

[3] K. K. Kuriakose, B. Raj, S. A. V. S. Murty, and P. Swaminathan, "Knowledge Management Maturity Models - A Morphological Analysis," J. Knowl. Manag. Pract., vol. 11, No. 3, 2010.

[4] A. Willem and M. Buelens, "Knowledge sharing in public sector organizations: The effect of organizational characteristics on interdepartmental knowledge sharing," J. Public Adm. Res. Theory, vol. 17, no. 4, pp. 581-606, 2007.
[5] M. A. Wibowo and R. Waluyo, "Knowledge management maturity in construction companies," Procedia Eng., vol. 125, pp. 89-94, 2015.

[6] Siemens, "Knowledge management maturity model (KMMM): Methodology for assessing and developing maturity in knowledge management," 2004.

[7] I. Becerra-Fernandez, \& R. Shaberwal (Eds.), Knowledge Management: System and Processes, $2^{\text {nd }}$ Ed., Routledge, New York, p.61, 2015

[8] Nonaka, I., \& Takeuchi, The knowledge creating company: how Japanese companies create the dynamics of innovation, New York, 1995

[9] F.F. Batista \& C.O. Quandt, "Knowledge management in the public sector: maturity levels of federal government organizations in Brazil," pp.54-61

[10] M. Eppler in F.F. Batista \& C.O. Quandt, "Knowledge management in the public sector: maturity levels of federal government organizations in Brazil," pp.54-61

[11] L.G., Pee and A., Kankanhalli, "A Model of Organizational Knowledge Management Maturity based on People, Process, and Technology", Journal of Information \& Knowledge Management, Vol. 8, No. 2, pp 79-99, 2009 
[12] T. Baykiz, An Assessment of knowledge management maturity among the public institutions in Turkey, Middle East Technical University, 2014

[13] L. Montañez-Carrilloa et. al., "Adaptation of the General Maturity Model of Knowledge Management (G-KMMM), " International Journal of Control Theories and Applications (IJCTA), Vol. 9, No. 44, pp. 129-134, India, 2016 